\title{
Biosorption of Cadmium Ions by Unmodified, Microwave and Ultrasound Modified Brewery and Pure Strain Yeast Biomass
}

\author{
Boldizsár Nagy ${ }^{1}$, Szende Tonk $^{2}$, Cerasella Indolean ${ }^{1}$, Andrada Măicăneanu ${ }^{1}$, Cornelia Majdik $^{{ }^{*}}$ \\ ${ }^{1}$ Faculty of Chemistry and Chemical Engineering, Babeş-Bolyai University, Cluj-Napoca, Romania \\ ${ }^{2}$ Faculty of Sciences and Arts, Sapientia Hungarian University of Transylvania, Cluj-Napoca, Romania \\ Email: *majdik@chem.ubbcluj.ro
}

Received May 14, 2013; revised June 14, 2013; accepted June 30, 2013

Copyright (C) 2013 Boldizsár Nagy et al. This is an open access article distributed under the Creative Commons Attribution License, which permits unrestricted use, distribution, and reproduction in any medium, provided the original work is properly cited.

\begin{abstract}
The present study investigates the biosorption of cadmium ions from aqueous solution onto unmodified, ultrasound and microwave treated cells of Saccharomyces cerevisiae. FTIR analysis was conducted to characterize the biosorbent. Equilibrium and kinetic studies of unmodified RBW (residual brewery waste) cell yeast and DSM 1333 (pure strain) were conducted by considering the effect of initial cadmium ions concentration. Results showed that the ultrasound and microwave treatments decrease the heavy metal uptake compared with the unmodified biomass. Langmuir and Freundlich isotherm models on both unmodified yeast cell types were used to analyze the equilibrium data. It was found that the Langmuir isotherm and pseudo-second-order kinetics models describe better the cadmium ions removal process.
\end{abstract}

Keywords: Biosorption; Heavy Metals; Saccharomyces cerevisiae Cells; Isotherm; Kinetics

\section{Introduction}

The presence of heavy metals in environment represents a major problem due to their harmful effects over human health and ecosystem. Many of these metals such as iron, manganese, copper, zinc, cobalt are essential nutrients for living organisms, but they become toxic at high levels. Other heavy metals like cadmium and lead exert their toxic effect even at low concentrations. With the rapid development of various industries like mining, metallurgy, electroplating and metal surface treating, wastes containing metals are directly or indirectly dispersed into the environment $[1,2]$. Cleaning these areas is necessary because of their future use, and their ability to eliminate the environmental impact. Currently, a high number of conventional processes are studied in detail, such as chemical precipitation, ion exchange, electrochemical treatment, membrane technologies etc., with the purpose of removing heavy-metal from wastewaters. Apart from being expensive, these technologies create secondary problems with metal bearing sludge [3]. An answer for this problem is given by one of the most promising techniques for the removal of heavy metals, which is biosorption. Bio-

*Corresponding author. sorption is a simple and attractive method, economically feasible for the removal of metal ions from wastewaters. Many researchers have tried several inexpensive, easily available materials. Different sorbents have been used for the removal of heavy metal ions such as sawdust [4], zeolite [5], mushrooms [6,7], sun flower [8], algae [9], yeast [10], etc. These materials contain functional groups associated with proteins, polysaccharide, lignin and cellulose as major constituents that play an important role in the metal uptake during sorption processes [11]. An important biosorbent widely investigated for its abilities in heavy metal removal is $S$. cerevisiae. This biomass can be obtained from the brewing industry (residual brewery waste) and/or grown in laboratory conditions (pure strain). It is therefore easily available and provides high removal capacity $[12,13]$. Several utilization techniques of the waste beer and pure strain yeast were applied to remove heavy metals. Goksungur et al. [14] studied the biosorption of cadmium and leads ions by ethanol treated waste baker's yeast biomass. Results showed that the treated yeast had a high biosoption capacity than native yeast. A comparison between acid treated and untreated culture tropical white-rot basidiomycete BDT-13 (DSM 
15396) on chromium (IV) was studied by Trivedi and Patel [13]. It was concluded that the acid treated fungal biomass shows a $100 \%$ metal adsorption capacity compared to the untreated biomass with a capacity of only $26.64 \%$. Biosorption of zinc by waste beer yeast was also investigated by Han et al. [15], who found that the adsorbed quantity is $\mathrm{pH}$ dependent. The capability of heat-treated $S$. cerevisiae was studied by Marcellino et al. [16]. This method demonstrated that heat-treated yeast is an efficient biomass in removal of $\mathrm{Sb}$ (III) at room temperature. Another form of treatment is the microwave and ultrasound irradiation. Microwaves energy is delivered directly into materials through molecular interaction with the electromagnetic field. Microwaves are electromagnetic waves with frequencies between $300 \mathrm{MHz}$ and $300 \mathrm{GHz}$. In microwave heating, the transfer of electromagnetic energy to thermal energy is an energy conversion [17]. Microwaves have been applied in many research areas such as medical waste sterilization, organic decomposition and disinfection of food, heating and chemical synthesis. This may be due to the rapid, uniform and selective heating of microwave radiation. U1trasound is a sound, with a variation of pressure or density with frequencies pitched above human hearing. U1trasound can be classified according to the frequency level as high frequency and low power $(2-10 \mathrm{MHz}$ range) and low frequency and high power $(20-100 \mathrm{kHz})$ ultrasound which are used for cleaning and welding. Chemical effects of ultrasound do not occur from a direct interaction with molecular species but from cavitation phenomena under formation, growth and implosive collapse of cavities in liquids where large amounts of highly localized energy are released [18,19].

The aim of this study was to investigate the biosorption potential of two types of yeast biomasses unmodified and microwaves and ultrasound modified. RBW (residual brewery waste) and DSM 1333 (pure strain) of residual beer yeast cells were used. The influence of contact time, initial cadmium concentration, microwaves irradiation intensity and ultrasound irradiation time were studied. Also, kinetics and isotherm model of unmodified biomass were considered in order to better describe the biosorption process.

\section{Materials and Methods}

\subsection{Biosorbent}

Two types of biosorbents that contain the same strain, namely $S$. cerevisiae were used for experiments. First biosorbent is a residual waste brewery yeast biomass (RBW). The brewery waste biomass was collected from CIUC brewery (Miercurea-Ciuc, Romania) after being used in fermentation processes and transported to the laboratory in airtight special containers. RBW samples were then washed with bi-distilled water and separated by vacuum filtration, dried in a hot air oven at $80^{\circ} \mathrm{C}$ for 24 hours. The second biosorbent is DSM 1333 pure strain yeast (DSM) was provided from University of Pécs, Hungary, Medical School, Department of Medical Microbiology and Immunology, in the lyophilized form. The composition of growth medium was Müller-Hinton substrate $(3 \%$ glucose, peptone, yeast-extra, $\mathrm{NaCl}, \mathrm{pH}=$ 7). The medium was sterilized by autoclaving at a pressure of $1.5 \mathrm{~atm}$ and a temperature of $121^{\circ} \mathrm{C}$ for $20 \mathrm{~min}-$ utes. The pure yeast culture was grown in an incubator at $30^{\circ} \mathrm{C}, 200 \mathrm{rpm}$ for $48 \mathrm{~h}$ (New Brunswick Scientific). During the growth process, yeast cells number was controlled by measuring the absorbance of the culture. After completing the yeast production, the suspension was centrifuged at $4500 \mathrm{rpm}$ for 30 minutes, and washed two times with sterile PBS (phosphate-buffer solution). Cells were then lyophilized and used in this form for all trials.

\subsection{Chemicals}

The stock solution, $1 \mathrm{~g}$ of Cadmium(II) was prepared by dissolving $\mathrm{Cd}\left(\mathrm{NO}_{3}\right)_{2} \cdot 4 \mathrm{H}_{2} \mathrm{O}$ salt, in distilled water. The required concentrations were obtained by diluting the stock solution to the different concentrations, 8 - 132 $\mathrm{mg} / \mathrm{L}$ cadmium. For heavy metals ions biosorption we used only synthetic monocomponent solutions. All chemicals used were of analytical grade.

\subsection{Microwave Assisted Irradiation}

For microwave irradiation, $1 \mathrm{~g}$ of RBW and DSM, respectively were suspended in $6 \mathrm{ml}$ distilled water. The quartz test tube with the suspended samples was inserted in the reactor where it was irradiated at 20 bar pressure, $100^{\circ} \mathrm{C}$ and 20 to $100 \mathrm{~W}$ powers. The microwave irradiated residual brewery yeast biomass (RBW-MW) and DSM (DSM-MW) samples were subsequently dried at $70^{\circ} \mathrm{C}$ for $8 \mathrm{~h}$. Finally the dried biomass was grinded into fine powder and used for further experiments. The irradiation was made by using a CEM Discover SP microwave reactor.

\subsection{Ultrasonic Assisted Irradiation}

The ultrasonic irradiation was carried out with an Elmasonic S 15 equipment operating at $37 \mathrm{kHz}$ (ultrasonic frequency). $1.5 \mathrm{~g}$ of RBW and DSM biomass was suspended in $8 \mathrm{ml}$ distillated water in a vessel which was then inserted in the thermostated bath of the ultrasonic equipment. The ultrasonic energy was dissipated over samples at 1, 3, 6, 12, 24 min time intervals. The ultrasonic irradiated residual brewery yeast biomass (RBWUS) and DSM (DSM-US) samples were subsequently dried at $70^{\circ} \mathrm{C}$ for $8 \mathrm{~h}$. Finally, the dried biomass was 
grinded into fine powder and used for further experiments.

\subsection{Adsorption Experiments}

The adsorption experiments were performed in batch condition, contacting $0.1 \mathrm{~g}$ biosorbent with $50 \mathrm{ml}$ aqueous solution of cadmium ions at different initial concentrations $(8-132 \mathrm{mg} / \mathrm{L})$, under stirring $(150 \mathrm{rpm})$, room temperature $\left(23^{\circ} \mathrm{C} \pm 2{ }^{\circ} \mathrm{C}\right)$ and $\mathrm{pH}=6.5$. In order to determine the exact concentration of cadmium ions and establish the evolution of the removal process, samples were collected at different time intervals (5 - $240 \mathrm{~min}$ ). At the end of predetermined time, samples were centrifuged at $10.000 \mathrm{rpm}$ for $5 \mathrm{~min}$, cadmium concentration was determined from the supernatant using an Atomic Absorption Spectrometer (SensAA Dual GBS Scientific Equipment, Australia). In order to evaluate the amount of heavy metals ions retained per unit mass of biomass, the biosorption capacity was calculated using the following equation:

$$
\mathrm{q}_{\mathrm{e}}=\frac{\left(\mathrm{C}_{0}-\mathrm{C}_{\mathrm{e}}\right) \cdot \mathrm{V}}{\mathrm{m}}
$$

where $\mathrm{q}_{\mathrm{e}}$ is the amount adsorbed at equilibrium $(\mathrm{mg} / \mathrm{g})$, $\mathrm{C}_{0}$ is the initial cadmium ions concentration (mg/L), $\mathrm{C}_{\mathrm{e}}$ is the equilibrium metal ions concentration $(\mathrm{mg} / \mathrm{L}), \mathrm{V}$ is the volume of the aqueous phase $(\mathrm{L})$, and $\mathrm{m}$ is the quantity of the biosorbent $(\mathrm{g})$.

Removal efficiency, E (\%), was calculated as ratio between heavy metals biosorbed at time $\mathrm{t}(\mathrm{mg} / \mathrm{L})$ and the initial cadmium ions concentration $(\mathrm{mg} / \mathrm{L})$ [20]:

$$
E(\%)=\frac{C_{0}-C_{t}}{C_{0}} \times 100
$$

\section{Results and Discussions}

\subsection{Effect of Contact Time and Initial Cadmium Ions Concentration}

The effect of contact time on cadmium biosorption proc-

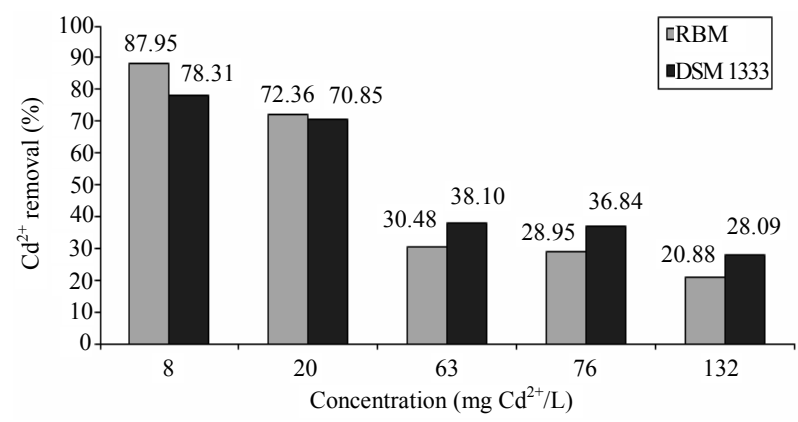

(a) ess for RBW and DSM yeast biomasses were studied. It was observed that the biosorbed quantity of cadmium ions increase as the contact time increases, and attains equilibrium in about $240 \mathrm{~min}$ (Figure 1). Following the evolution in time, the removal of cadmium ions is rapid in the first 10 minutes from the beginning of the experiment.

After that it gradually decreases until equilibrium is reached. This may be due to the large number of adsorption sites available at the beginning, while towards the end of the experiment fewer sites are available for biosorption. Hence, $240 \mathrm{~min}$ was chosen as the equilibrium time for each experiment.

The cadmium ions biosorption RBW and DSM yeast biomass is significantly influenced by the initial cadmium concentration in aqueous solution (Figures 2(a) and (b)). We can observe an increase in the biosorption capacity and a decrease of the removal efficiency with a concentration increase. The concentration provides an important driving force to overcome mass transfer resistance of the metal between aqueous and solid phase.

\subsection{Adsorption Kinetics}

Kinetics model were applied to data obtained at cadmium removal on RBW and DSM biomass. Pseudo-first- and

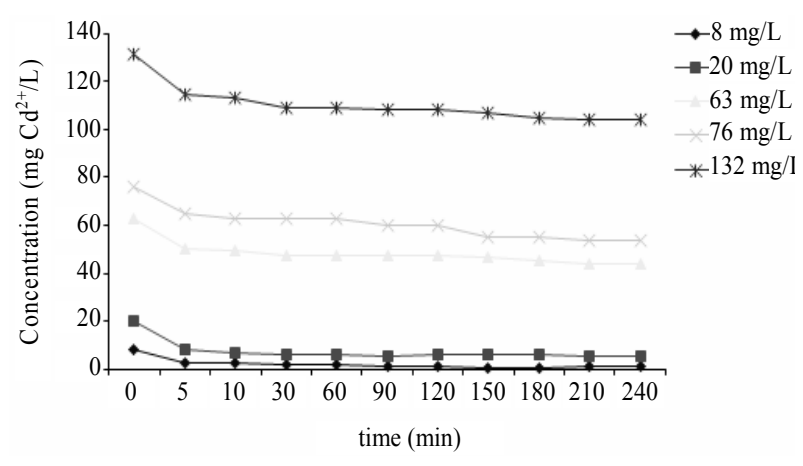

Figure 1. Effect of contact time and initial concentration on the biosorption of $\mathrm{Cd}^{2+}$ on $\mathrm{RBW}$ biomass; $23^{\circ} \mathrm{C} \pm 2^{\circ} \mathrm{C}, \mathrm{pH}=$ 6.5, $150 \mathrm{rpm}$.

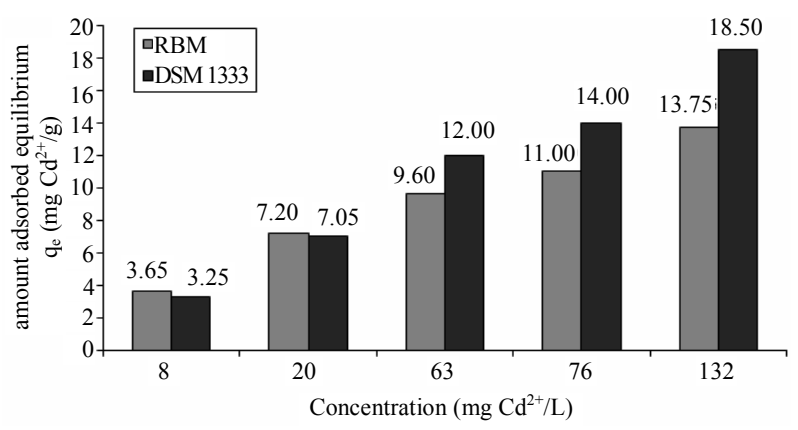

(b)

Figure 2. Influence of the initial $\mathrm{Cd}^{2+}$ concentration over (a) removal efficiency and (b) biosorption capacity of RBW and DSM biomass; $23^{\circ} \mathrm{C} \pm 2^{\circ} \mathrm{C}, \mathrm{pH}=6.5,150 \mathrm{rpm}$. 
pseudo-second-order models were used [21].

Linear form of pseudo-first-order kinetic model (Lagergren) is given by equation:

$$
\frac{d q_{t}}{d t}=k_{2}\left(q_{e}-q_{t}\right)^{2}
$$

where $\mathrm{q}_{\mathrm{t}}$ and $\mathrm{q}_{\mathrm{e}}$ are the amounts of cadmium adsorbed $(\mathrm{mg} / \mathrm{g})$ at equilibrium and time $\mathrm{t}$ respectively, and $\mathrm{k}_{1}$ is the rate constant of first-order adsorption ( $1 / \mathrm{min})$. In order to determine the rate constant and biosorption capacity for cadmium uptake, the straight line plots of $\log \left(\mathrm{q}_{1}-\mathrm{q}\right)$ against $t$, were made at different initial concentrations.

Linear form of pseudo-second-order kinetic model (Ho's model):

$$
\frac{1}{q_{e}-q_{t}}=\frac{1}{q_{e}}+k_{2} t
$$

where $\mathrm{k}_{2}$ is the rate constant of pseudo-second-order ad- sorption $\left(\mathrm{g} / \mathrm{mg}\right.$ min). The values $\mathrm{q}_{\mathrm{e}}$ and $\mathrm{k}_{2}$ are determined from the slope and intercept of the $t / q_{t}$ versus $t$ plot.

The correlation coefficients $\left(\mathrm{R}^{2}\right)$ obtained for the pseudo-first-order kinetic model were low $(0.873-0.9688)$ and the calculated $\mathrm{q}_{\mathrm{e}}$ values show great differences when compared to experimental values (Table 1, Figure 3(a)). Therefore, the considered biosorption process cannot be described by pseudo-first-order kinetic model (for neither one of the two biomass samples).

The correlation coefficients for the second-order kinetic model are greater than 0.9900 and 0.9955 for RBW and DSM, respectively. Also, the calculated $\mathrm{q}_{\mathrm{e}}$ values are very close to the experimental ones (Table 1, Figure 3(b)). These results indicate that the cadmium ions adsorption kinetics on the two yeast biomass is better described by the pseudo-second-order kinetic model, suggesting that the considered process takes place mainly as chemisorption.

Table 1. Pseudo-first- and pseudo-second-order rate constants, calculated and experimental $\mathrm{q}_{\mathrm{e}}$ values for cadmium ions bio-

\begin{tabular}{|c|c|c|c|c|c|c|c|}
\hline \multirow{2}{*}{$\mathrm{C}(\mathrm{mg} / \mathrm{L})$} & \multirow{2}{*}{$\mathrm{q}_{\mathrm{e}}(\exp )(\mathrm{mg} / \mathrm{g})$} & \multicolumn{3}{|c|}{ Pseudo-first-order } & \multicolumn{3}{|c|}{ Pseudo-second-order } \\
\hline & & $\mathrm{k}_{1}(1 / \mathrm{min})$ & $\mathrm{q}_{\mathrm{e}}($ calc) $(\mathrm{mg} / \mathrm{g})$ & $\mathrm{R}^{2}$ & $\mathrm{k}_{2}(\mathrm{~g} / \mathrm{mg} \cdot \min )$ & $\mathrm{q}_{\mathrm{e}}(\mathrm{calc})(\mathrm{mg} / \mathrm{g})$ & $\mathrm{R}^{2}$ \\
\hline \multicolumn{8}{|c|}{ RBW } \\
\hline 8 & 3.65 & $3.89 \times 10^{-2}$ & 1.56 & 0.7942 & $4.69 \times 10^{-2}$ & 3.76 & 0.9975 \\
\hline 20 & 7.2 & $2.48 \times 10^{-2}$ & 1.41 & 0.5747 & $7.48 \times 10^{-2}$ & 7.19 & 0.9993 \\
\hline 63 & 9.6 & $1.63 \times 10^{-2}$ & 4.09 & 0.6787 & $0.88 \times 10^{-2}$ & 9.59 & 0.9834 \\
\hline 75 & 11.00 & $2.82 \times 10^{-2}$ & 8.52 & 0.873 & $0.33 \times 10^{-2}$ & 11.78 & 0.9588 \\
\hline 132 & 13.76 & $2.51 \times 10^{-2}$ & 6.83 & 0.827 & $0.68 \times 10^{-2}$ & 13.95 & 0.992 \\
\hline \multicolumn{8}{|c|}{ DSM } \\
\hline 8 & 3.25 & $3.23 \times 10^{-2}$ & 0.99 & 0.8057 & $8.19 \times 10^{-2}$ & 3.27 & 0.9995 \\
\hline 20 & 7.05 & $2.63 \times 10^{-2}$ & 3.15 & 0.8644 & $1.60 \times 10^{-2}$ & 7.16 & 0.9955 \\
\hline 63 & 12.00 & $3.28 \times 10^{-2}$ & 10.97 & 0.9688 & $0.25 \times 10^{-2}$ & 13.35 & 0.9872 \\
\hline 75 & 14.00 & $2.87 \times 10^{-2}$ & 2.83 & 0.7334 & $2.64 \times 10^{-2}$ & 14.00 & 0.9994 \\
\hline 132 & 18.5 & $2.58 \times 10^{-2}$ & 13.36 & 0.8487 & $0.21 \times 10^{-2}$ & 19.53 & 0.9524 \\
\hline
\end{tabular}
sorption on RBW and DSM biomass using different initial concentrations; $C_{i}=8-132 \mathrm{mg} / \mathrm{L}, 23^{\circ} \mathrm{C} \pm 2^{\circ} \mathrm{C}, \mathrm{pH}=6.5,150 \mathrm{rpm}$.

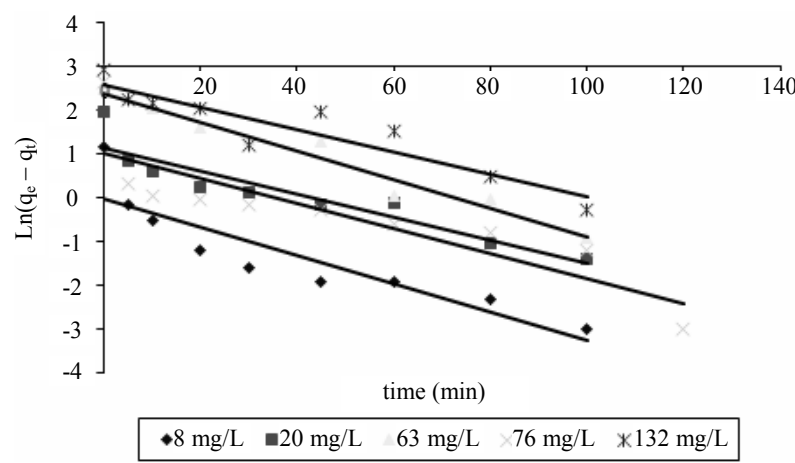

(a)

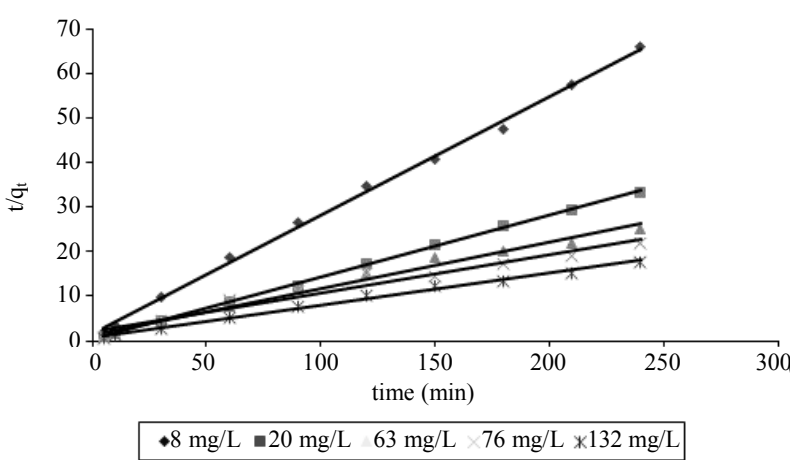

(b)

Figure 3. (a) Plots of the pseudo-first-order model for $\mathrm{Cd}^{2+}$ biosorption on DSM biomass; (b) Plots of the pseudo-second-order model for $\mathrm{Cd}^{2+}$ biosorption on RBW biomass. 


\subsection{Equilibrium Isotherm Models}

Langmuir and Freundlich models were used to determine the adsorption equilibrium between the biosorbent and metal ions.

The Langmuir model assumes that a monomolecular layer is formed when biosorption takes place without any interaction between the adsorbed molecules [22]. Freundlich isotherm is an empirical equation based on a heterogeneous adsorption due to the diversity of adsorption sites or diverse nature of the adsorbed metal ions, free or hydrolysed species [23].

The Langmuir isotherm linear equation is expressed as follows:

$$
\frac{1}{\mathrm{q}_{\mathrm{e}}}=\frac{1}{\mathrm{q}_{\max } \cdot \mathrm{b}} \cdot \frac{1}{\mathrm{C}_{\mathrm{e}}}+\frac{1}{\mathrm{q}_{\max }}
$$

where $\mathrm{q}_{\mathrm{e}}$ is the solid-phase adsorbate concentration at equilibrium ( $\mathrm{mg} / \mathrm{g}), \mathrm{q}_{\max }$ is the maximum adsorption capacity corresponding to the monolayer adsorption capacity $(\mathrm{mg} / \mathrm{g}), \mathrm{C}_{\mathrm{e}}$ is the concentration of cadmium solution at equilibrium $(\mathrm{mg} / \mathrm{L})$, and $\mathrm{b}$ is the adsorption equilibrium constant that is related to the apparent energy of adsorption. Isotherm parameters $\mathrm{q}_{\max }$ and $\mathrm{b}$ can be obtained from $1 / \mathrm{q}_{\mathrm{e}}$ versus $\mathrm{C}_{\mathrm{e}}$ plot.

The Freundlich isotherm linear equation is expressed by the following equation:

$$
\log \mathrm{q}_{\mathrm{e}}=\log \mathrm{k}+\frac{1}{\mathrm{n}} \cdot \log \mathrm{C}_{\mathrm{e}}
$$

where $\mathrm{k}$ is related to adsorption capacity, and $\mathrm{n}$ is related

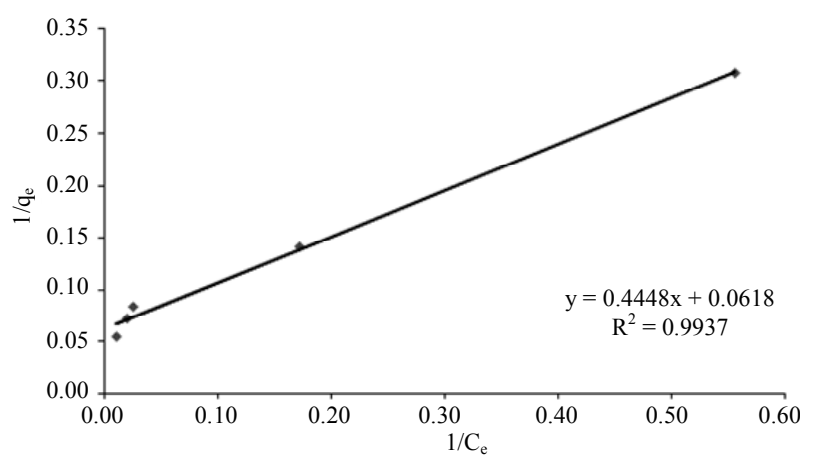

(a) to intensity of adsorption.

The $\ln q_{e}$ versus $\ln C_{e}$ plot allows the determination of the Freundlich constants.

The linear plots of the two considered isotherm and calculated coefficients are presented in Figures 4(a) and (b), Table 2. According to Langmuir isotherm, the monolayer adsorption capacity at equilibrium was 10.83 and $16.18 \mathrm{mg} / \mathrm{g}$ for RBW and DSM yeast biomass, respectively. These suggest that the considered biosorbents have high ability to retain cadmium ions from aqueous solutions. To conclude, after having been used in fermentation process, the ability of RBW biomass is smaller than that of the DSM yeast. The relatively high values of $\mathrm{k}$ and $\mathrm{n}$ Freundlich constants confirm the fact that the two types of yeast biomass have high adsorption capacity and increased adsorption intensity with respect to the considered metal ion. From the calculated regression coefficient values $\left(\mathrm{R}^{2}\right)$ can be suggested that the biosorption of cadmium ions onto RBW and DSM biomass are better described by the Langmuir model.

\subsection{Effect of Biomass Treatment on Cadmium Ions Uptake at Room Temperature}

The yeast cell wall is composed of two main layers. The outer layer contains heavily glycosylated mannoproteins, whereas the inner layer is mainly constituted of $\beta 1-3-$ glucans and chitin representing about $50 \%-60 \%$ of the wall dry weight. Also, the carbohydrate side chains of the cell surface proteins contain multiple phosphodiester bridges $[24,25]$.

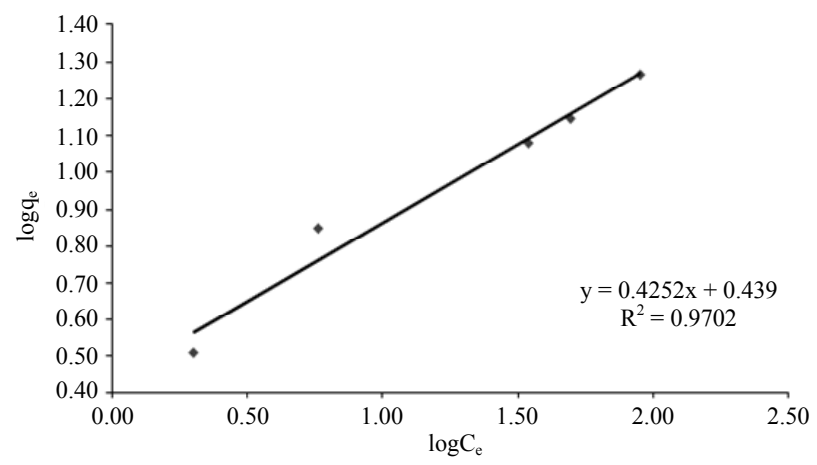

(b)

Figure 4. (a) Langmuir plot for $\mathrm{Cd}^{2+}$ biosorption on DSM biomass; (b) Freundlich plot for $\mathrm{Cd}^{2+}$ biosorption on DSM biomass.

Table 2. Langmuir and Freundlich coefficients calculated using linear regression analysis for cadmium ions biosorption on RBW and DSM biomass; $\mathrm{C}_{\mathrm{i}}=8-132 \mathrm{mg} / \mathrm{L}, 23^{\circ} \mathrm{C} \pm 2^{\circ} \mathrm{C}, \mathrm{pH}=6.5,150 \mathrm{rpm}$.

\begin{tabular}{cccccc}
\hline & Langmuir coefficients & & \multicolumn{2}{c}{ Freundlich coefficients } \\
\hline & $\mathrm{B}(\mathrm{L} / \mathrm{mg})$ & $\mathrm{q}_{\max }(\mathrm{mg} / \mathrm{g})$ & $\mathrm{R}^{2}$ & $\mathrm{n}$ & $\mathrm{K}_{(\mathrm{mg}}^{(1-1 / \mathrm{n})} \mathrm{L}^{1 / \mathrm{n} / \mathrm{g})}$ \\
$\mathrm{RBW}$ & 0.017 & 10.83 & 0.9822 & 3.83 & 3.95 \\
$\mathrm{R}$ & 0.027 & 16.18 & 0.9937 & 2.35 & 0.9604 \\
\hline
\end{tabular}


The results obtained under ultrasonic irradiation are presented in Figures 5(a) and (b). The removal capacity of cadmium ions decreases with the increase of contact time in comparison with the control sample (absence of ultrasound). At lower intensity (contact time 1, 3 and 6 min), the implosion of cavity produces moderate modifications in cells structure, therefore, a slow increase was observed in the removal of cadmium ions for both studied yeast biomass. However, a short contact time was enough to reduce the biosorption capacity compared to the control sample. By increasing the time of ultrasound irradiation (12 - $24 \mathrm{~min}$ ), a major decrease on cadmium uptake was observed. This behavior can be explained by the cavitation processes that affects directly the damages on yeast cell wall.

By microwave irradiation of RBW and DSM biomass cell suspension, a major degradation of complex structure was observed. These cells modifications were observed in reduction of cadmium ions uptake, shown in

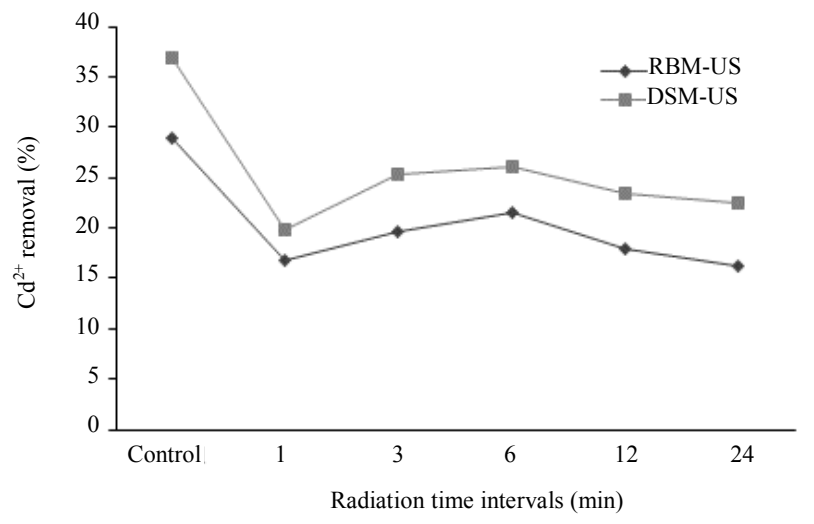

(a)
Figures 6(a) and (b). As the figures show, there is a constant decrease in the removal efficiency and biosorption capacity. As a result of the microwave irradiation, the number of viable cells was rapidly reduced or destroyed, decreasing the active sites number on the cell walls. These active sites play an important role in the binding of cadmium ions. Similar results were reported in literature after different chemical treatments were applied. Microwave irradiation on temperatures above $60^{\circ} \mathrm{C}$ reduces the number of viable cells on E. coli [26]. Thermal treatments onto different cell suspensions of Aspergillus carbonarius for $2 \mathrm{~h}$ at $50^{\circ} \mathrm{C}$ led to an important decrease of $\mathrm{Cu}^{2+}$ uptake [27] or Cr(VI) accumulation by Neurospora crassa [28].

This significant modification on cell wall structure of the two types of yeast biomass was confirmed by FTIR spectra analysis before and after ultrasound and microwave modifications (Figures 7(a) and (b)). Significant changes were observed in the microwave treated DSM,

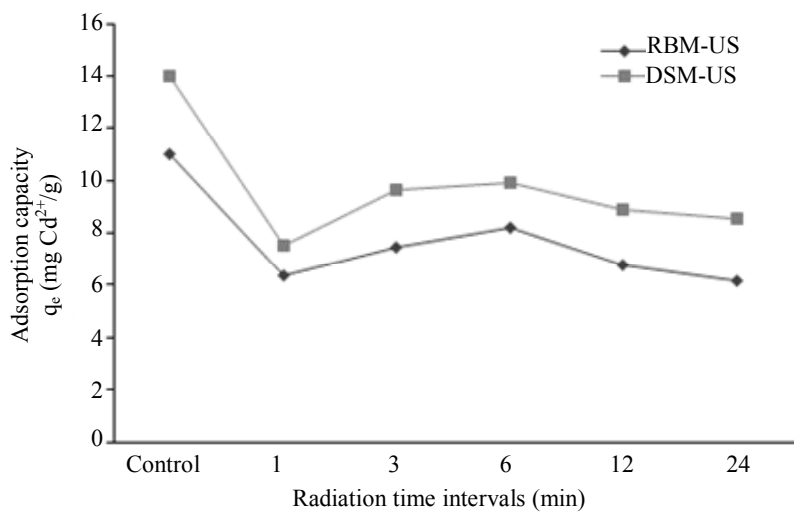

(b)

Figure 5. (a) Ultrasound irradiation effect over removal efficiency of cadmium ions biosorption on RBW and DSM biomass; $\mathrm{C}_{\mathrm{i}}=8-132 \mathrm{mg} / \mathrm{L}, 23^{\circ} \mathrm{C} \pm 2^{\circ} \mathrm{C}, \mathrm{pH}=6.5,150 \mathrm{rpm}$; (b) Ultrasound irradiation effect over biosorption capacity of cadmium ions biosorption on RBW and DSM biomass; $\mathrm{C}_{\mathrm{i}}=8-132 \mathrm{mg} / \mathrm{L}, 23^{\circ} \mathrm{C} \pm 2^{\circ} \mathrm{C}, \mathrm{pH}=6.5,150 \mathrm{rpm}$.

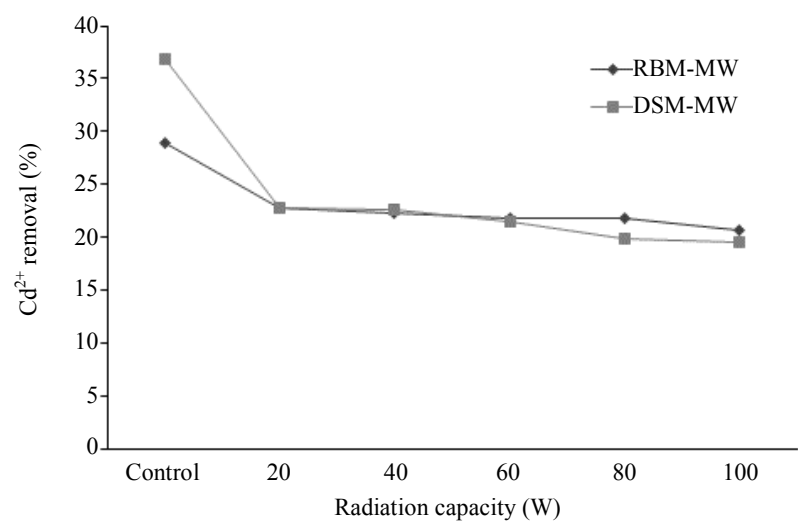

(a)

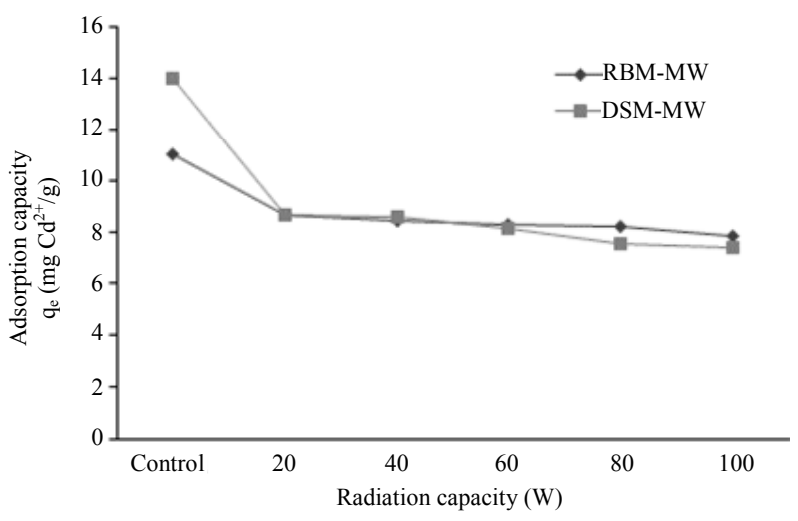

(b)

Figure 6. (a) Microwave irradiation effect over the removal efficiency of cadmium ions biosorption on RBW and DSM biomass; $\mathrm{C}_{\mathrm{i}}=8-132 \mathrm{mg} / \mathrm{L}, 23^{\circ} \mathrm{C} \pm 2^{\circ} \mathrm{C}, \mathrm{pH}=6.5,150 \mathrm{rpm}$; (b) Microwave irradiation effect over the biosorption capacity of cadmium ions biosorption on $\mathrm{RBW}$ and $\mathrm{DSM}$ biomass; $\mathrm{C}_{\mathrm{i}}=8-132 \mathrm{mg} / \mathrm{L}, 23^{\circ} \mathrm{C} \pm 2^{\circ} \mathrm{C}, \mathrm{pH}=6.5,150 \mathrm{rpm}$. 


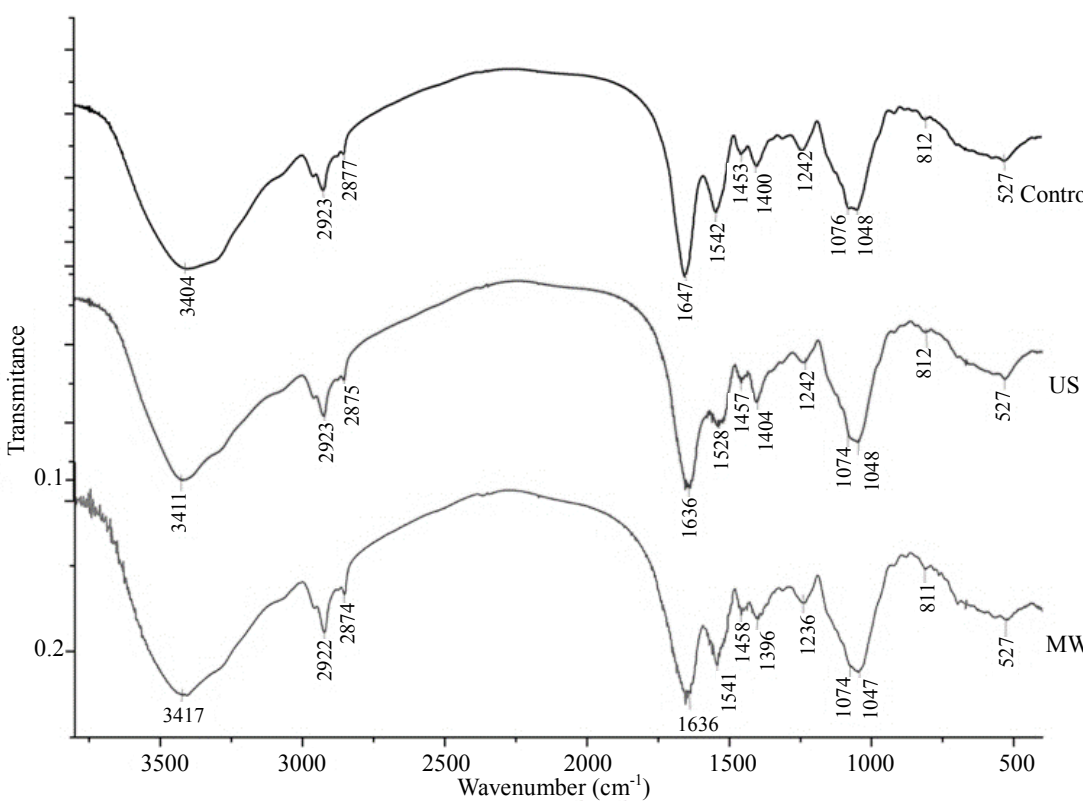

(a)

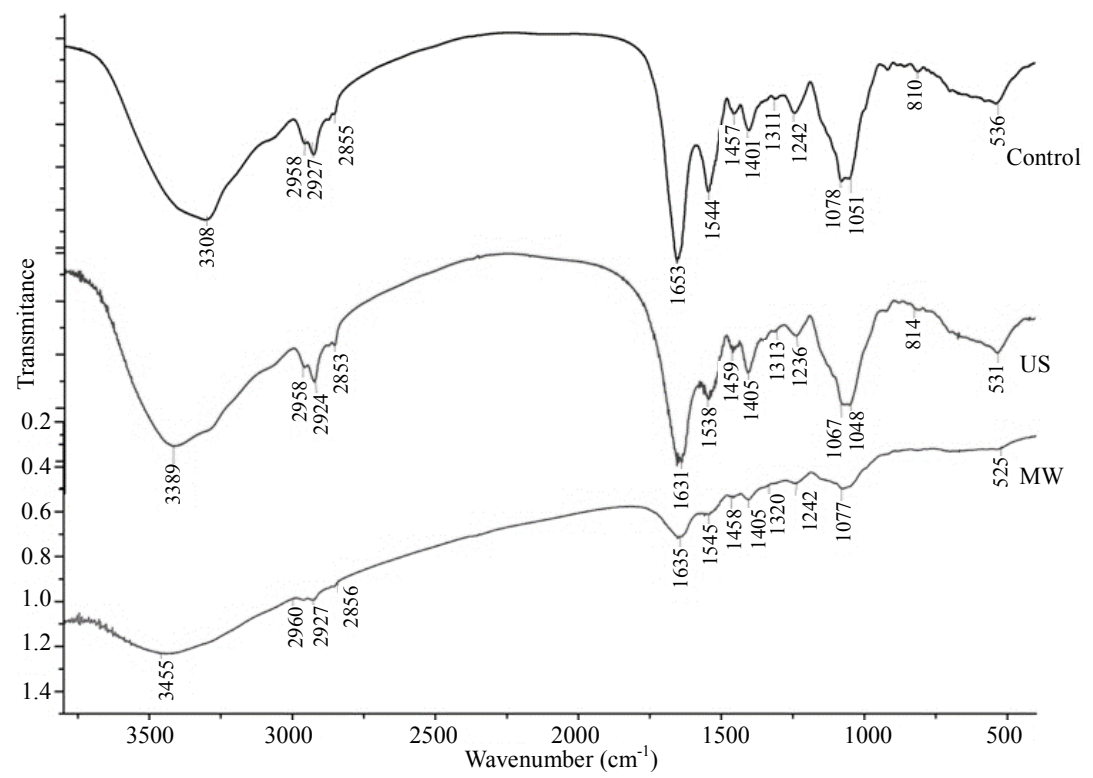

(b)

Figure 7. (a) FTIR spectra of the ultrasound and microwave modified RBW biomass; (b) FTIR spectra of the ultrasound and microwave modified DSM biomass.

where the spectra show a deformation compared to the control sample. The wide and intense bands at around 3417 - $3389 \mathrm{~cm}^{-1}$ showed the most significant changes due to the microwave and ultrasound treatments. These bands can be assigned to the stretching of O-H and N-H of proteins and peptides group from macromolecular association. The $2927-2922 \mathrm{~cm}^{-1}$ region includes absorption vibrations mainly assigned to lipids $-\mathrm{CH}_{3}-\mathrm{CH}_{2}$ groups. These variations can be related to the biochemical changes from the disorganization of the membrane system, especially of the plasmatic membrane [29]. The weak band at $2877-2853 \mathrm{~cm}^{-1}$ is assigned to $-\mathrm{CH}$ - bond of methylene group. The major bands at $1647-1631$ $\mathrm{cm}^{-1}$ correspond to the amide $\mathrm{I}$ (mainly $\mathrm{C}=\mathrm{O}$ stretching) and amide II (C-N stretching and N-H bending) bands of proteins and peptides. Results show that proteins are partially damaged by the applied treatments. The peaks at $1545-1528 \mathrm{~cm}^{-1}$ originate from symmetric $\mathrm{C}=\mathrm{O}$ stretching bands of the carboxylate ion group of terminal amino acid [30,31]. Two wide absorption bands around 1459 and $1453 \mathrm{~cm}^{-1}$ are characteristic to proteins and peptides and their intensity increase after treatments due to the 
relative increase in lipid content, as well as to protein degradation in transmission spectra [29]. The vibrations from $1242-1236 \mathrm{~cm}^{-1}$ interval can be assigned to the free amino acids. The behavior of the wide peaks in 1078 - $1047 \mathrm{~cm}^{-1}$ range, corresponding to the stretch vibration of $\mathrm{C}-\mathrm{O}$ in the carbohydrate region, decreased drastically over the microwave treatment on DSM biomass. Furthermore, spectra of $<900 \mathrm{~cm}^{-1}$ region show significant changes in the degradation of the mannans and $\beta$ 1-3glucans which are widely present on yeast cell wall. These results suggest that the degradation of these essential groups following the microwave and ultrasound treatments had a great impact on binding cadmium ions by RBW and DSM biomass.

\section{Conclusions}

This study presented the results obtained at cadmium ions biosorption on unmodified and ultrasound and microwave modified $S$. cerevisiae cell yeast biomass. Two types of this yeast, RBW (residual brewery waste) and DSM 1333 (pure strain), were subjected to ultrasound and microwave treatments.

The effect of contact time and initial cadmium ions concentration in solution for the two types of unmodified biomass were studied. Following the biosorption process, a contact time of 240 min was necessary to reach equilibrium, depending on cadmium ion initial concentration. Also, high cadmium ions concentration favored the biosorption process. Maximum biosorption capacities of 13.94 and $19.53 \mathrm{mg} / \mathrm{g}$ were obtained experimentally, while 10.83 and $16.18 \mathrm{mg} / \mathrm{g}$ were obtained from Langmuir model for RBW and DSM, respectively. Equilibrium (Langmuir and Freundlich isotherm) and kinetics (pseudo-first- and pseudo-second-order) of the considered biosorption process were discussed in detail. Equilibrium was best described by the Langmuir isotherm and by the pseudo-second-order kinetics for both types of studied biomass.

Ultrasound and microwave treatments over RBW and DSM biomass showed a substantial decrease in cadmium ion binding compared to the control samples (unmodified biomass). These may be due, as FTIR spectral analysis confirms, to the destruction and damaging of the main important functional groups on the yeasts cell wall. The yeast cell wall components (lipids, proteins, mannans and different types of glucans) play an important role in the process of cadmium ions binding.

\section{Acknowledgements}

This work was made possible by the financial support of the Sectoral Operational Programme for Human Resources Development 2007-2013, co-financed by the European Social Fund, under the project POSDRU/107/
1.5/S/76841 with the title "Modern Doctoral Studies: Internationalization and Interdisciplinary".

\section{REFERENCES}

[1] P. L. Bishop, "Pollution Prevention: Fundamentals and Practice,” Tsinghua University Press, Beijing, 2002.

[2] B. Volesky, "Biosorption and Biosorbents," In: B. Volesky, Ed., Biosorption of Heavy Metals, CRC Press, Boca Raton, 1990, pp. 3-5.

[3] D. Brady, A. Stoll and F. R. Duncan, "Biosorption of Heavy Metal Cations by Nonviable Yeast Biomass," Environmental Technology, Vol. 15, No. 5, 1994, pp. 419-428. doi:10.1080/09593339409385447

[4] P. Chakravarty, N. S. Sarma and H. P. Sarma, "Biosorption of Cadmium (II) from Aqueous Solution Using Hearwood Powder of Areca Catechu," Chemical Engineering Journal, Vol. 162, No. 3, 2010, pp. 949-955. doi:10.1016/j.cej.2010.06.048

[5] A. M. El-Kamash, A. A. Zaki and M. Abed El Geleel, "Modeling Batch Kinetics and Thermodynamics of Zinc and Cadmium Ions Removal from Waste Solutions Using Synthetic Zeolite A," Journal of Hazardous Materials, Vol. 127, No. 1-3, 2005, pp. 211-220. doi:10.1016/j.jhazmat.2005.07.021

[6] R. Vimala and N. Das, "Biosorption of Cadmium (II) and Lead (II) from Aqueous Solutions Using Mushrooms: A Comparative Study," Journal of Hazardous Materials, Vol. 168, No. 1, 2009, pp. 376-382. doi:10.1016/j.jhazmat.2009.02.062

[7] M. J. Melgar, J. Alonso and M. A. García, "Removal of Toxic Metals from Aqueous Solutions by Fungal Biomass of Agaricus macrosporus," Science of the Total Environment, Vol. 385, No. 1-3, 2007, pp. 12-19.

doi:10.1016/j.scitotenv.2007.07.011

[8] A. Witek-Krowiak, "Analysis of Temperature-Dependent Biosorption of $\mathrm{Cu}^{2+}$ Ions on Sunflower Hulls: Kinetics, Equilibrium and Mechanism of the Process," Chemical Engineering Journal, Vol. 192, 2012, pp. 13-20. doi:10.1016/j.cej.2012.03.075

[9] Y. Liu, Q. Cao, F. Luo and J. Chen, "Biosorption of $\mathrm{Cd}^{2+}$, $\mathrm{Cu}^{2+}, \mathrm{Ni}^{2+}$ and $\mathrm{Zn}^{2+}$ Ions from Aqueous Solutions by Pretreated Biomass of Brown Algae," Journal of Hazardous Materials, Vol. 163, No. 2-3, 2009, pp. 931-938. doi:10.1016/j.jhazmat.2008.07.046

[10] Sz. Tonk, A. Măicăneanu, C. Indolean, S. Burcă and C. Majdik, "Application of Immobilized Waste Brewery Yeast Cells for $\mathrm{Cd}^{2+}$ Removal. Equilibrium and Kinetics," Journal of the Serbian Chemical Society, Vol. 76, No. 3, 2011, pp. 363-373. doi:10.2298/JSC100527032T

[11] A. Ahmad, M. Rafatullah and M. Danish, "Sorption Studies of Zn(II)- and Cd(II) Ions from Aqueous Solution on Treated Sawdust of Sissoowood," Holz als Roh- und Werkstoff, Vol. 65, No. 6, 2007, pp. 429-436. doi:10.1007/s00107-007-0175-7

[12] R. Hana, H. Li, Y. Li, J. Zhang, H. Xiao and J. Shi, "Biosorption of Copper and Lead Ions by Waste Beer Yeast," Journal of Hazardous Materials, Vol. 137, No. 3, 
2006, pp. 1569-1576. doi:10.1016/j.jhazmat.2006.04.045

[13] B. D. Trivedi and K. C. Patel, "Biosorption of Hexavalent Chromium from Aqueous Solution by a Tropical Basidiomycete BDT-14 (DSM 15396)," World Journal of Microbiology Biotechnology, Vol. 23, No. 5, 2007, pp. 683-689. doi:10.1007/s11274-006-9284-4

[14] Y. Goksungur, S. Uren and U. Guvenc, "Biosorption of Cadmium and Lead Ions by Ethanol Treated Waste Baker's Yeast Biomass," Bioresource Technology, Vol. 96, No. 1, 2005, pp. 103-109. doi:10.1016/j.biortech.2003.04.002

[15] R. P. Han, L. Zhu, J. S. Yin, X. P. Wu and Y. H. Li, "Zinc Cation Biosorping Studies by Yeast," Journal of Zhengzhuou University, Vol. 31, 1999, pp. 76-79.

[16] S. Marcellino, H. Attar, D. Lièvremont, M.-C. Lett, F. Barbierd and F. Lagardea, "Heat-Treated Saccharomyces cerevisiae for Antimony Speciation and Antimony(III) Preconcentration in Water Samples," Analytica Chimica Acta, Vol. 629, No. 1-2, 2008, pp. 73-83. doi:10.1016/j.aca.2008.09.031

[17] Y. F. Huang, W. H. Kuan, S. L. Lo and C. F. Lin., "Total Recovery of Resources and Energy from Rice Straw Using Microwave-Induced Pyrolysis," Bioresource Technologies, Vol. 99, No. 17, 2008, pp. 8252-8258. doi:10.1016/i.biortech.2008.03.026

[18] E. V. Rokhina, P. Lens and J. Virkutyte, "Low-Frequency Ultrasound in Biotechnology: State of the Art," Trends in Biotechnology, Vol. 27, No. 5, 2009, pp. 298-306. doi:10.1016/j.tibtech.2009.02.001

[19] K. S. Suslick, "Sonochemistry," Science, Vol. 247, No. 4949, 2009, pp. 1439-1445. doi:10.1126/science.247.4949.1439

[20] B. Yasemin and T. Zeki, "Removal of Heavy Metals from Aqueous Solution by Sawdust Adsorption," Journal of Environmental Sciences, Vol. 19, No. 2, 2007, pp. 160166. doi:10.1016/S1001-0742(07)60026-6

[21] Y. S. Ho and G. McKay, "The Kinetics of Sorption of Divalent Metal Ions onto Sphagnum Moss Peat," Water Research, Vol. 34, No. 3, 2000, pp. 735-742. doi:10.1016/S0043-1354(99)00232-8

[22] I. Langmuir, "The Adsorption of Gases on Plane Surfaces of Glass, Mica and Platinum," Journal of the American
Chemical Society, Vol. 40, No. 9, 1918, pp. 1361-1367. doi: $10.1021 / \mathrm{ja} 02242 \mathrm{a} 004$

[23] H. M. F. Freundlich, "Über die Adsorption in Lösungen," Zeitschrift für Physikalische Chemie, Vol. 57A, 1906, pp. 385-470.

[24] S. Marcellino, H. Attar, D. Lievremont, M.-C. Lett, F. Barbier and F. Lagarde, "Heat-Treated Saccharomyces cerevisiae for Antimony Speciation and Antimony(III) Preconcentration in Water Samples," Analytica Chimica Acta, Vol. 629, No. 1-2, 2008, pp. 73-83. doi:10.1016/j.aca.2008.09.031

[25] F. M. Klis, P. Mol, K. Hellingwerf and S. Brul, "Dynamics of Cell Wall Structure in Saccharomyces cerevisiae," FEMS Microbiology Reviews, Vol. 26, No. 3, 2002, p. 239. doi:10.1111/j.1574-6976.2002.tb00613.x

[26] I.-S. Woo, I.-K. Rhee and H.-D. Park, "Differential Damage in Bacteria Cells by Microwave Radiation on Basis of Cell Structure," Applied and Environmental Microbiology, Vol. 66, No. 5, 2000, pp. 2243-2247. doi:10.1128/AEM.66.5.2243-2247.2000

[27] S. Al-Asheh and Z. Duvnjak, "Adsorption of Copper and Chromium by Aspergillus carbonarius," Biotechnology Progress, Vol. 11, No. 6, 1995, p. 638. doi: $10.1021 / \mathrm{bp} 00036 \mathrm{a} 006$

[28] E. Lopez-Errasquin and C. Vasquez, "Tolerance and Uptake of Heavy Metals by Trichoderma atroviride Isolated from Sludge," Chemosphere, Vol. 50, No. 1, 2003, pp. 137-143. doi:10.1016/S0045-6535(02)00485-X

[29] E. Burattini, M. Cavagna, R. Dell'Anna, F. M. Campegi, F. Monti, F. Rossi and S. Torriani, "A FTIR Microspectroscopy Study of Autolysis in Cells of the Wine Yeast Saccharomyces cerevisiae," Vibrational Spectroscopy, Vol. 47, No. 2, 2008, pp. 139-147. doi:10.1016/j.vibspec.2008.04.007

[30] Z. Lin, J. Wu, R. Xue and Y. Yang, "Spectroscopic Characterization of $\mathrm{Au}^{3+}$ Biosorption by Waste Biomass of Saccharomyces cerevisiae," Spectrochimica Acta, Vol. 61, No. 4, 2005, pp. 761-765. doi:10.1016/j.saa.2004.03.029

[31] R. M. Silverstein, G. C. Bassler and T. C. Morill, "Infrared Spectometry," In: D. Sawicki and J. Stiefel, Eds., Spectrometric Identification of Organic Compounds, 5th Edition, John Wiley \& Sons, New York, 1991, p. 125. 